\title{
Titanium surface modification by using microwave-induced argon plasma in various conditions to enhance osteoblast biocompatibility
}

\author{
Gyeung Mi Seon ${ }^{1,2 \dagger}$, Hyok Jin Seo ${ }^{1,2 \dagger}$, Soon Young Kwon ${ }^{1}$, Mi Hee Lee ${ }^{1}$, Byeong-Ju Kwon ${ }^{1,2}$, Min Sung Kim ${ }^{1,2}$, \\ Min-Ah Koo ${ }^{1,2}$, Bong Joo Park ${ }^{3}$ and Jong-Chul Park ${ }^{1,2^{*}}$
}

\begin{abstract}
Background: Titanium is a well proven implantable material especially for osseointegratable implants by its biocompatibility and anti-corrosive surface properties. Surface characteristics of the implant play an important role for the evolution of bone tissue of the recipient site. Among the various surface modification methods, plasma treatment is one of the promising methods for enhance biocompatibility. We made microwave-induced argon plasma at atmospheric pressure to improve in titanium surface biocompatibility.

Results: Various states of emission spectra from excited species-argon, nitrogen atoms and oxygen atoms were observed. The electron energy band structures are the unique characteristics of atoms and functional groups. Microwaveinduced argon plasma treatment changed the titanium surface to be very hydrophilic especially on the $5 \mathrm{~s}$ short treatment and $30 \mathrm{~s}, 90 \mathrm{~s}$ long treatment samples that detected by contact angle measurement. MC3T3-E1 attachment and proliferation assay significantly increased in $5 \mathrm{~s}$ at short treatment, $30 \mathrm{~s}$, and $90 \mathrm{~s}$ at long treatment after 5 days incubation.
\end{abstract}

Conclusions: Result indicated that microwave-induce argon plasma treatment would be an effective method to modify titanium surface for enhancing cell-material interactions.

Keywords: Titanium, Microwave-induced argon plasma, Surface modification, Biocompatibility

\section{Background}

The success of a dental implant is based on the osseointegration that is defined as the direct contact between the bone tissue and the dental implant surface, without fibrous tissue growing at the interface [1,2]. Titanium is a well proven implantable material especially for dental and orthopedic implants [3-5]. The popularity of titanium for osseointegratable implants is based on its biocompatibility and anti-corrosive surface properties. Surface characteristics of the implant play an important role for the evolution of bone tissue of the recipient site, after implantation [6,7]. In order to further enhance its biocompatibility, several special

\footnotetext{
* Correspondence: parkjc@yuhs.ac

${ }^{\dagger}$ Equal contributors

${ }^{1}$ Cellbiocontrol Laboratory, Department of Medical Engineering, Yonsei University College of Medicine, 134 Shinchon-dong, Seodaemun-gu, Seoul 120-752, Republic of Korea

${ }^{2}$ Brain Korea 21 PLUS Project for Medical Science, Yonsei University College of Medicine, 134 Shinchon-dong, Seodaemun-gu, Seoul 120-752, Republic of Korea

Full list of author information is available at the end of the article
}

treatments to create surfaces such as sandblasted large-grit and acid-etched (SLA) surface, resorbable blasted media (RBM) surface and micro-arc oxidized (MAO) surfaces were conventionally used.

Among the various surface modification methods, plasma treatment is one of the promising methods. Diverse functional groups could be introduced to the surface by various appropriate plasma sources. These functional groups improve biocompatibility of the surface and enhance cellular responses [8]. An atmospheric plasma system is commonly used for sterilization and surface modification. As previously, our laboratory made microwave-induced argon plasma at atmospheric pressure. This system provided good sterilization effects on microorganisms, fungi, Escherichia coli, Methicillin-resistant staphylococcus aureus and mycotoxins [9-12]. Also, surface modification effects on various biomaterials such as PLGA, polyurethane and silk fibroin were investigated by microwave-induced argon plasma [13-15]. 
In this study, microwave-induced argon plasma was adopted to enhance titanium surface biocompatibility, and different distance from nozzle and treating time were controlled to confirm the effects of this plasma system. Distances between sample and nozzle were set to $3 \mathrm{~cm}$ and $7 \mathrm{~cm}$. For convenience, 'short treatment' stands for the test of $3 \mathrm{~cm}$ distance and 'long treatment' stands for the test of $7 \mathrm{~cm}$ distance.

\section{Methods}

\section{Materials}

Thickness and diameter of the CP-2 titanium (Ti) specimens (Seoul Titanium Inc., Korea) were $0.3 \mathrm{~mm}$ and $13 \mathrm{~mm}$. The specimens were solvent-cleaned by a serial ultrasonic treatment in acetone, methyl alcohol and deionized water, and then dried with oxygen blow.

\section{Treatment of microwave-induced argon plasma}

Self-designed microwave-induced argon plasma was used in this study as previously described [9]. Briefly, this system consisted of $2.45 \mathrm{GHz}$ magnetron power supply $(1 \mathrm{~kW})$, an applicator including a tuning section and the nozzle made of quartz. The microwave was introduced through a WR-284 copper waveguide with internal cross section dimensions of $72 \mathrm{~mm} \times 24 \mathrm{~mm}$. The plasma generated at the end of a nozzle was formed by an interaction between the high electrical fields, which is generated by the microwave power supply, the waveguide aperture and the gas nozzle. The electric field intensity around the nozzle was calculated by a high frequency structure simulator (HFSS) code simulation as previously described [11]. Argon was used as a working gas for this plasma system, which was chosen for its inertness, and the gas flow rate is approximately $100 \mathrm{~min}^{-1}$ at $8 \mathrm{~kg}_{\mathrm{f}} / \mathrm{cm}^{2}$. For evaluating the plasma efficiency on $\mathrm{Ti}$ disks, Ti disks were placed in front of a nozzle in the plasma system and exposed to plasma for $1 \mathrm{~s}, 5 \mathrm{~s}$ at 'short treatment $(3 \mathrm{~cm})$ ' and $10 \mathrm{~s}, 30 \mathrm{~s}, 90 \mathrm{~s}$ at 'long treatment $(7 \mathrm{~cm})^{\prime}$, respectively.

\section{Measurement of emission spectra}

The emission spectra from the plasma according to the gas type were acquired through the optical fiber in the range of 200-1200 nm wavelength. The optical emission spectrometer (HR4000, Ocean Optics Inc, USA) was used to analyze the emission spectra and the electronically excited species generated by the plasma device. The measurement point has been set to be just region of plasma plume. The optical emission spectrum was obtained from the plasma device.

\section{Contact angle measurement}

Contact angle was measured using the sessile drop method [16]. to evaluate hydrophilicity of prepared specimens. De- ionized water was utilized as probing liquid. Surface energy was also measured by same method. Three samples were used to collect the contact angle data in diiodomethane, formamide and glycerol for each plasma treated titanium. Lewis acids and bases were used to calculate the surface energy [17].

\section{Cell culture}

MC3T3-E1 mouse pre-osteoblastic cell line (Riken, Japan) was maintained in QMEM medium modified with ascorbic acid supplemented with $10 \%$ fetal bovine serum and $1 \%$ antibiotic antimycotic solution (WelGENE, Korea). Cells were cultured at $37{ }^{\circ} \mathrm{C}$ in a humidified $5 \% \mathrm{CO}_{2}$ atmosphere incubator.

\section{Cell attachment and proliferation test}

Microwave-induced argon plasma treated $\mathrm{Ti}$ disks were placed to 24 well plate and the titanium disks were sterilized in $70 \%$ ethanol for $30 \mathrm{~min}$ and washed three times in distilled water. After sterilization, MC3T3-E1 cells were seeded on titanium disks at a density of $6 \times 10^{4}$ cells/disk and incubated for $2 \mathrm{~h}$ for cell attachment test. For cell proliferation test, cells were seeded at a density of $3 \times 10^{4}$ cells/disk and cultured for $1,3,5$ days in a $\mathrm{CO}_{2}$ incubator. The viability of the cells was determined with 3-(4, 5-dimethylthiazol-2-yl)-2,5-diphenyltetrazolium bromide (MTT) assay. Briefly, MTT was added to each well at $500 \mu \mathrm{g} / \mathrm{mL}$ and further incubated for $4 \mathrm{~h}$ at $37^{\circ} \mathrm{C}$. After incubation, dimethyl sulfoxide and glycine buffer was added to each well for the solubilization of the formed formazan salts. The absorbance of each well was measured spectrophotometrically at $570 \mathrm{~nm}$ by a microplate reader.

\section{Cell morphometric analysis}

For cell morphometric analysis, the cells were seeded at the initial seeding density of $1.0 \times 10^{4}$ cells/disk and after $2 \mathrm{~h}$ of incubation they were fixed with ice cold $70 \%$ ethanol. Cell plasma membrane was visualized by staining with Texas Red C2-maleimide (Texas Red, $30 \mathrm{ng} / \mathrm{ml}$ in PBS, Invitrogen) [18]. Cell nuclei were counterstained with Hoechst 33258 ( $1 \mathrm{~g} / \mathrm{ml}$ in PBS, Sigma). Ten random pictures were taken by IX-70 microscope, equipped with a DP-71 digital camera (Olympus, Japan). Cell attachment area, perimeter and Feret's diameter of 30 cells for each group were measured by Image J software (NIH, USA) [19].

\section{Statistical analysis}

All results were statistically analyzed by Student $t$-test. Data are expressed as mean \pm standard error of mean. $P$ values $<0.05$ were considered statistically significant. 


\section{Results}

Optical emission spectroscopy (OES)

The emission spectra of the microwave-induced argon plasma were collected by optical emission spectroscopy (OES) in order to probe the existence of excited nitrogen derivatives. Various states of emission spectra from excited species-argon atoms $(696,706,727,738,750,763$, 772, 795, 801, $811 \mathrm{~nm})$, nitrogen atoms (337, 357, 373, $378 \mathrm{~nm})$ and oxygen atoms $(777 \mathrm{~nm})$ were observed and the spectra were depicted in Fig. 1. Excited $\mathrm{OH}$ molecular emissions around $308 \mathrm{~nm}$ were also observed [20-23].

\section{Contact angle measurement}

Changes of contact angle and surface energy on the plasma treated titanium surfaces were summarized in Tables 1 and 2. The water contact angle of untreated titanium surface was $54.8^{\circ}$ and it fell to nearly zero degree on the $90 \mathrm{~s}$ treated sample at 'long treatment'. Figure 2 shows change of contact angle by de-ionized water drop. When titanium sample was placed in the short treatment,
Table 1 Long treatment condition; contact angle and surface energy on plasma treated titanium $(n=3)$

\begin{tabular}{lllll}
\hline & $0 \mathrm{~s}$ & $10 \mathrm{~s}$ & $30 \mathrm{~s}$ & $90 \mathrm{~s}$ \\
\hline Formamide $\left({ }^{\circ} \mathrm{C}\right)$ & 39.06 & 0 & 0 & 0 \\
Glycerol $\left({ }^{\circ} \mathrm{C}\right)$ & 44.09 & 18.69 & 14.47 & 8.60 \\
Diiodomethane $\left({ }^{\circ} \mathrm{C}\right)$ & 26.70 & 22.57 & 19.89 & 15.91 \\
Surface energy $\left(\mathrm{mJ} / \mathrm{m}^{2}\right)$ & 791.53 & 672.07 & 953.65 & 1274.84 \\
\hline
\end{tabular}

$5 \mathrm{~s}$ treated samples showed similar effects to $30 \mathrm{~s}$ treatment in the long treatment. The results of surface energy provide more detailed comparison between 'short treatment' and 'long treatment' (Tables 1 and 2). The surface energy of $5 \mathrm{~s}$ treated titanium at 'short treatment' was $1026.74 \mathrm{~mJ} / \mathrm{m}^{2}$ and the results of $30 \mathrm{~s}$ and $90 \mathrm{~s}$ treatments at 'long treatment' were $953.65 \mathrm{~mJ} / \mathrm{m}^{2}$ and $1274.84 \mathrm{~mJ} / \mathrm{m}^{2}$, repectively. Put differently, the effect of $5 \mathrm{~s}$ treatment at 'short treatment' was similar to the result of $30 \mathrm{~s}$ or $90 \mathrm{~s}$ at 'long treatment'. Even though OES could not detect any

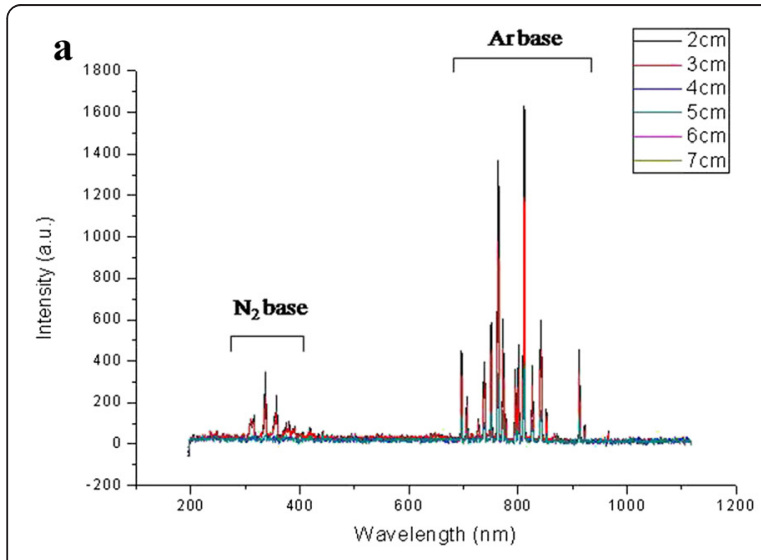

c

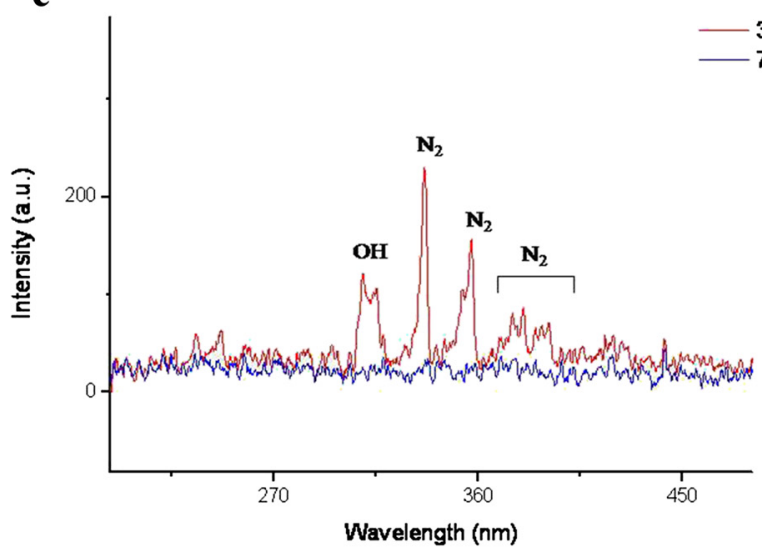

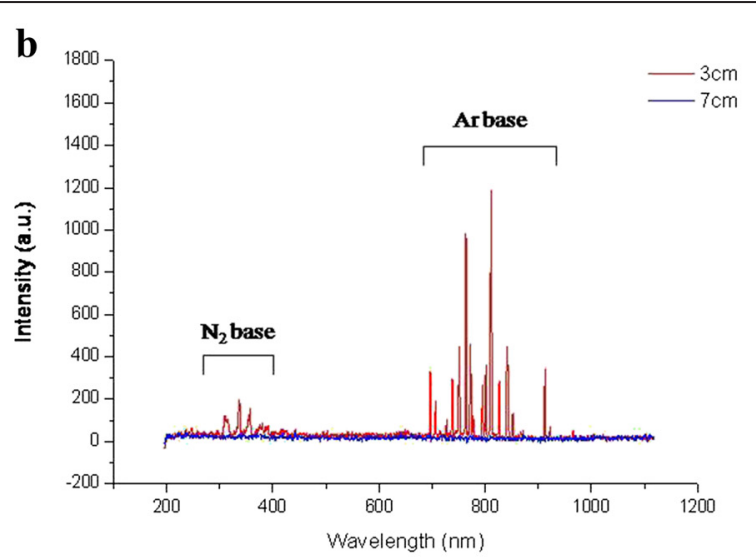

d

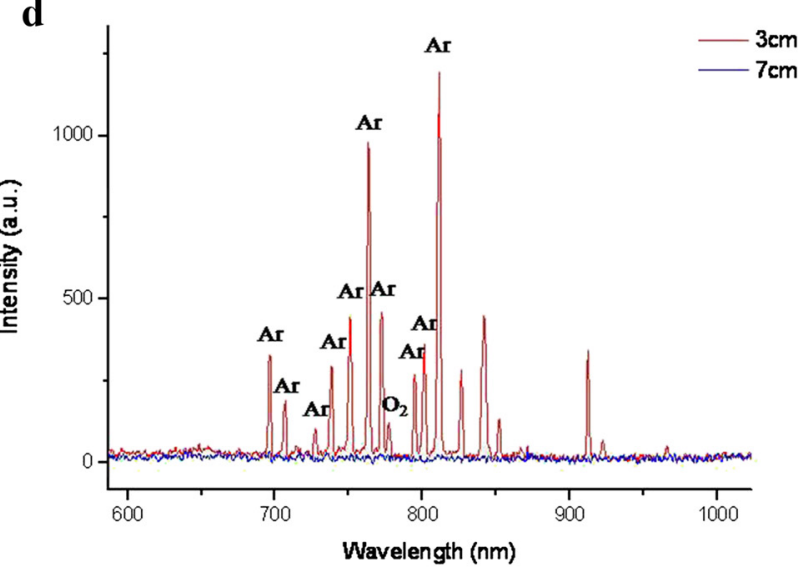

Fig. 1 Emission spectra of microwave-induced argon plasma. (a) Comparison of plasma spectra exited in different distance from nozzle. (b) Different emission spectra between 'short treatment' and 'long treatment'. (c) Emission spectra of N2 base. (d) Emission spectra of Ar base 
Table 2 Short treatment condition; contact angle and surface energy on plasma treated titanium $(n=3)$

\begin{tabular}{llll}
\hline & $0 \mathrm{~s}$ & $1 \mathrm{~s}$ & $5 \mathrm{~s}$ \\
\hline Formamide $\left({ }^{\circ} \mathrm{C}\right)$ & 39.06 & 0 & 0 \\
Glycerol $\left({ }^{\circ} \mathrm{C}\right)$ & 44.09 & 15.08 & 13.57 \\
Diiodomethane $\left({ }^{\circ} \mathrm{C}\right)$ & 26.70 & 22.35 & 18.14 \\
Surface energy $\left(\mathrm{mJ} / \mathrm{m}^{2}\right)$ & 791.53 & 895.10 & 1026.74 \\
\hline
\end{tabular}

emission spectra at 'long treatment', radicals and photons were still existed at 'long treatment'.

\section{MC3T3-E1 attachment and proliferation}

The number of attached MC3T3-E1 cells cultured for $2 \mathrm{~h}$ on the plasma treated titanium was showed in Fig. 3. When titanium was placed under the long treatment, $30 \mathrm{~s}$ and $90 \mathrm{~s}$ treatments are positively effective for attachment. The $30 \mathrm{~s}$ and $90 \mathrm{~s}$ treated samples showed significantly enhanced attachment compared to control $(0 \mathrm{~s})$. When titanium was placed under the short treatment, cell attachment was significantly enhanced after $5 \mathrm{~s}$ treatment.

Enhanced proliferation patterns of MC3T3-E1 cultured for 1,3 and 5 days on the plasma treated titanium were plotted in Fig. 4. After 3 days incubation, the number of cells at 'long treatment' was significantly increased after $90 \mathrm{~s}$ plasma treatment and the number of cells after $30 \mathrm{~s}$ treatment was also significantly increased after 5 days incubation. Moreover, in the short treatment test, cell proliferation was increased just in $5 \mathrm{~s}$ treatment time.

\section{Cell morphometric analysis}

Fluorescence images of cells on the titanium disks visualizing the plasma membrane by Texas Red maleimide staining have shown that, the attached cells on plasma treated samples were increased in population and also obviously enlarged. Cells adhering to non-treated disks were smaller and round-shaped, while cells on microwave induced plasma treated disks occupied larger attachment area, well-spread elongated morphology with formed lamellipodia-like projections (Figs. 5 and 6). Population of cells also increased after plasma treatment. This result means that the ratio of initially attached cells increased after plasma treatment.

The area, perimeter and Feret's diameter of the attached MC3T3-E1 were measured and plotted in Figs. 5 and 6 . All of the measured parameters increased significantly on the plasma treated titanium regardless of the treating time and treating condition.

\section{Discussion}

Gaseous plasma provides a complex body of radicals, ions, electrons, and photons which are in various excited energy states. The optical emission spectra from the energy quenching processes of the excited species can be performed to characterize the plasma. The electron energy band structures are the unique characteristics of atoms and functional groups. Since the atmospheric pressure discharge was fired at ambient atmosphere, the emissions from not only excited argon atoms but also excited nitrogen and oxygen atoms and $\mathrm{OH}$ molecules could be detected. The emission spectra of the microwaveinduced argon plasma were collected by optical emission spectroscopy (OES) in order to probe the existence of excited nitrogen derivatives. Compared to the short treatment, the long treatment could not be detected by OES. OES can observe the optical atmosphere and the long treatment cannot provide optical condition. Although emission spectra of the long treatment were not detected, radicals and electrons were still existed at the atmosphere. This phenomenon is easily understood by contact angle analysis.

Microwave-induced argon plasma treatment changed the titanium surface to be very hydrophilic. In general, surface hydrophilicity is very important for homogeneous and sufficient surface-compatibility as well as for good growth of cells on polymer materials [24]. Furthermore, it was reported that enhanced fibronectin adsorption and reduced albumin adsorption occurs on hydrophilic

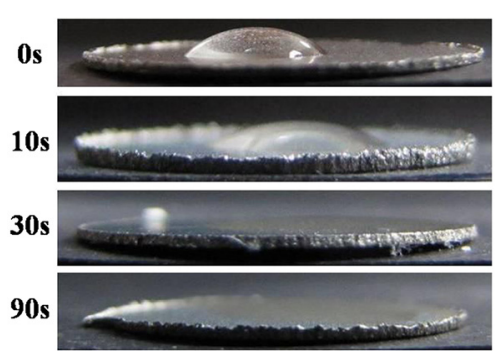

a

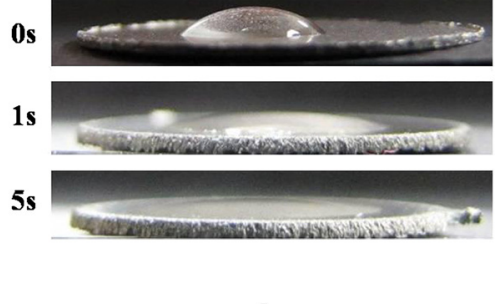

b

Fig. 2 Change of hydrophilicity on plasma treated titanium surface. (a) Long treatment group (7 cm). (b) Short treatment group (3 cm) 

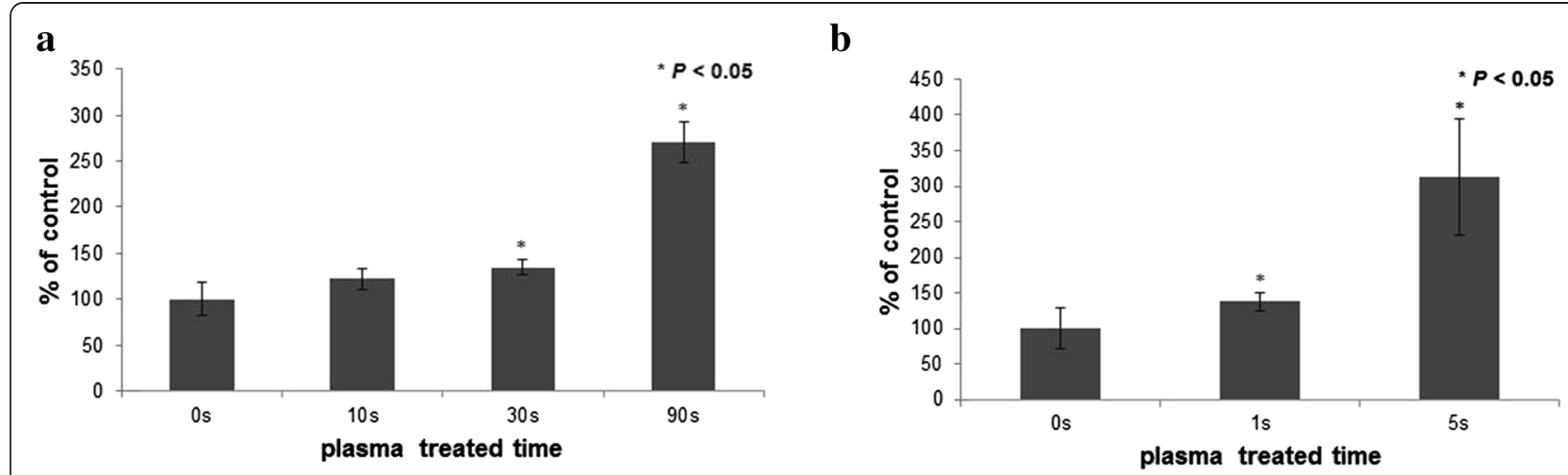

Fig. 3 MC3T3-E1 cell attachment on plasma treated titanium surface by plasma treated time. (a) Long treatment condition; MC3T3-E1 attachment test on titanium surface for $2 \mathrm{~h}$ by MTT assay (b) Short treatment condition; MC3T3-E1 attachment test on titanium surface for $2 \mathrm{~h}$ by MTT assay

surfaces and these elongated fibronectin conformation on the hydrophilic surface was effected to cell attachment [19]. This plasma system could produce super-hydrophilic surface even for the short period time in the short treatment condition. In the long treatment condition, the surface had changed to super-hydrophilic after $90 \mathrm{~s}$ even though the OES was not detected at this point. In case of $\mathrm{UV}$ modification, $48 \mathrm{~h}$ treatment time is required to decrease the water contact angle of machined surface to less than $10^{\circ}$. It might be resulted from the high population of various exited species that only short treatment time of microwave-induced argon plasma was required to achieve super-hydrophilic surface, which is a typical characteristic of atmospheric pressure gaseous discharge.

To confirm the effects of this plasma system for cellular responses, different treating conditions were adopted on this study. The initial interaction of cells with the biomaterial plays a key role for and early acceptance of the implant [25]. In previous study, we confirmed that titanium surface treated helium atmospheric pressure glow discharge (He-APGD) promoted selectively higher absortion of fibronectin, a protein of critical importance for cell/biomaterial interaction. Therefore, we expected the improved cell response appeared to be dependent on the fibronectin-integrin mediated mechanism of cell attachment [26]. In this sense, cell attachment and proliferation test was performed on the plasma treated titanium surface. Cell morphometric analysis is also performed to confirm changed cell morphology after plasma treatment. These results support that the microwave induced argon plasma system which was used for this study could be very useful to enhance cellular responses on titanium surface for both the short treatment and the long treatment. Even though this plasma has very strong power which can be used for sterilization microorganisms in a very short time, it can be controlled very easily by changing the position of samples.

\section{Conclusions}

Microwave-induced argon plasma system was employed to modify titanium surface in order to achieve enhanced biological responses. Plasma treated titanium surface
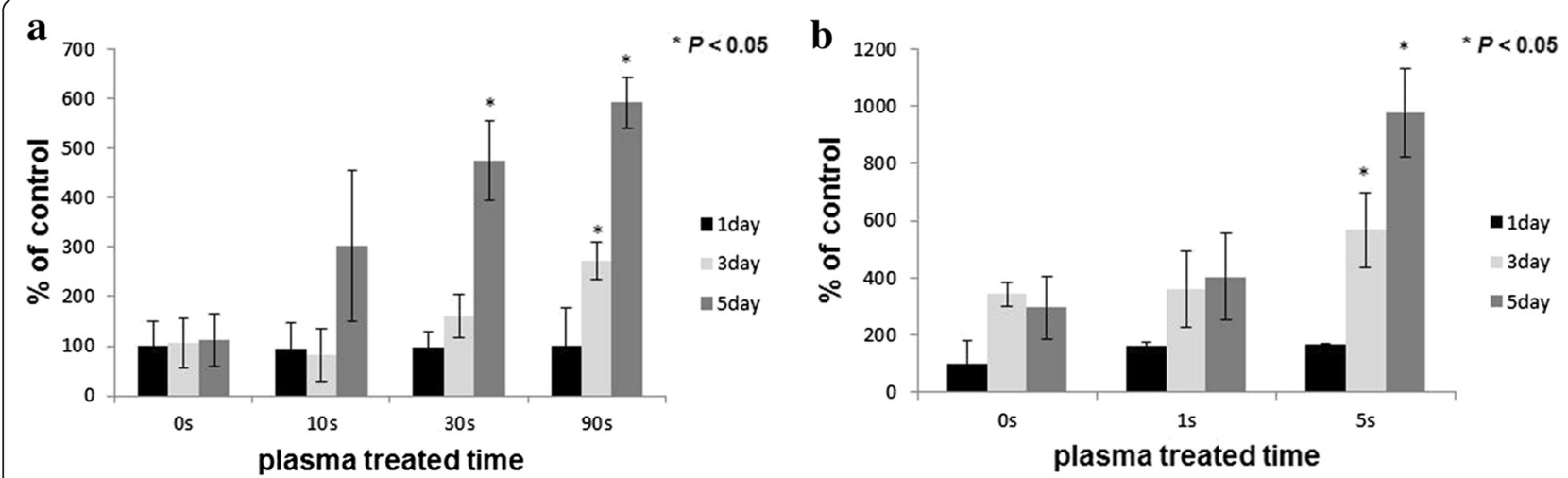

Fig. 4 MC3T3-E1 cell proliferation on plasma treated titanium surface by plasma treated time. (a) Long treatment condition; MC3T3-E1 proliferation test on titanium surface by MTT assay (b) Short treatment condition; MC3T3-E1 proliferation test on titanium surface by MTT assay 


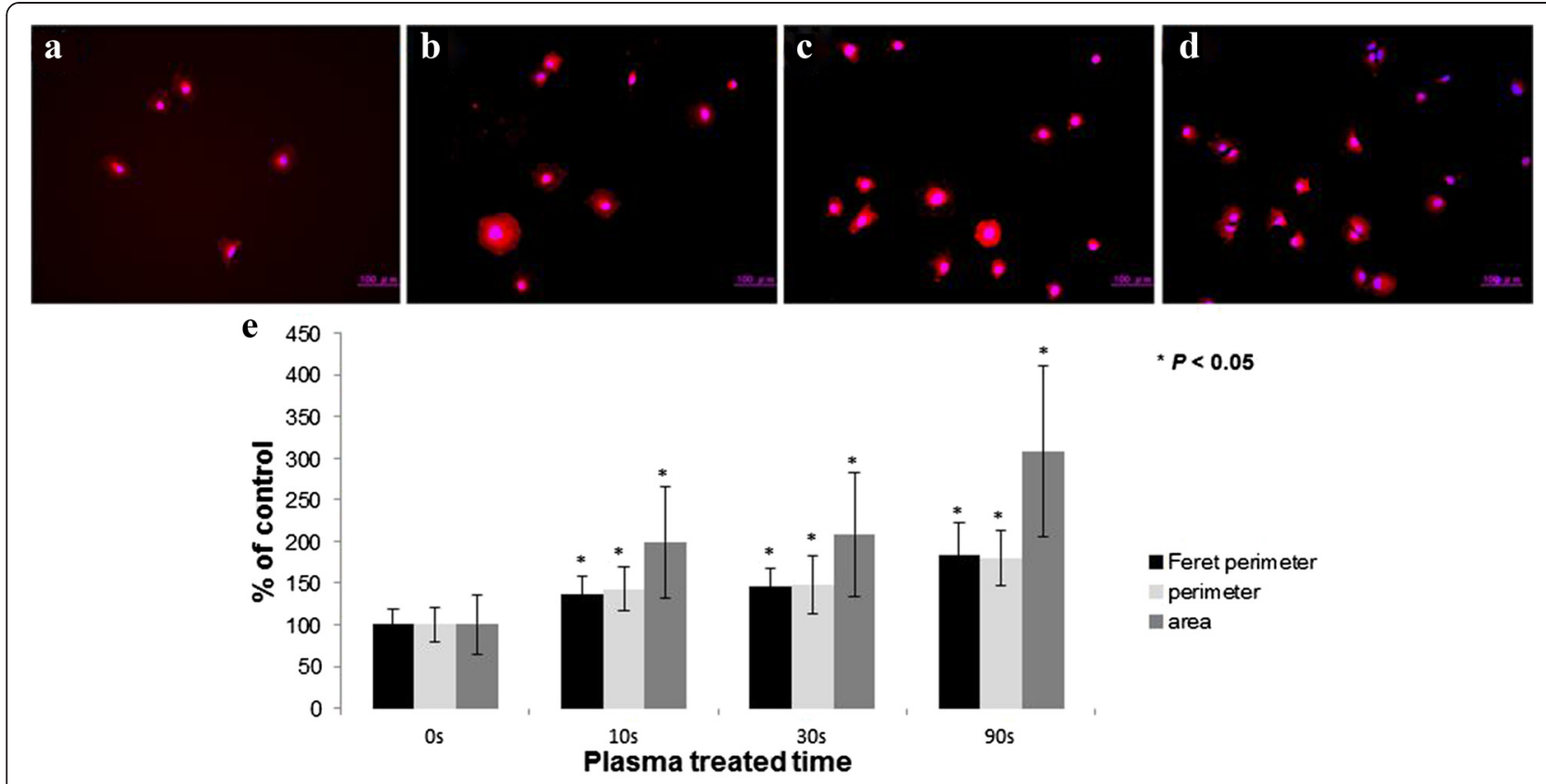

Fig. 5 Long treatment condition; Change of morphology of attached MC3T3-E1 cells on plasma treated titanium. (a) Untreated sample. (b) 10 s treated sample. (c) $30 \mathrm{~s}$ treated sample. (d) $90 \mathrm{~s}$ treated sample. (e) Relative morphometric analysis of attached MC3T3-E1 cells on plasma treated titanium

turned to be very hydrophilic surface and it did not require more than $90 \mathrm{~s}$ treatment time. Surface modified titanium by plasma treatment increased surface energy and it allowed enhancing cell attachment and proliferation on the titanium surface. The increase of cell population, cell area, perimeter, and Feret's diameter of MC3T3-E1 cells were also promoted. Conclusively, microwave-induce argon plasma treatment would be an effective method to modify titanium surface for enhancing cell-material interactions.
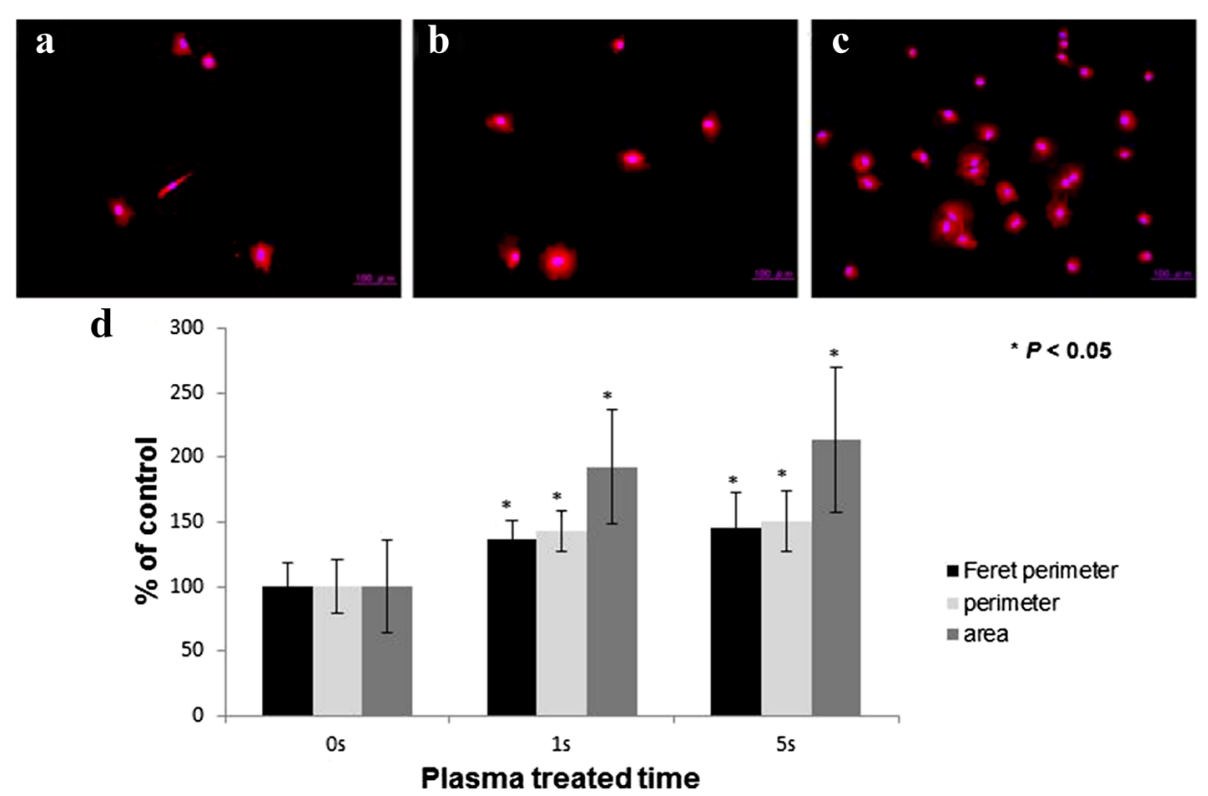

Fig. 6 Short treatment condition; Change of morphology of attached MC3T3-E1 cells on plasma treated titanium. (a) Untreated sample. (b) $1 \mathrm{~s}$ treated sample. (c) $5 \mathrm{~s}$ treated sample. (d) Relative morphometric analysis of attached MC3T3-E1 cells on plasma treated titanium 


\section{Competing interests}

The authors declare that they have no competing interests.

\section{Authors' contributions}

GMS and HJS designed the experiments, carried out analysis of Titanium surface modification by microwave-induced argon plasma and drafted the manuscript. MHL participated in the design of the study and performed the statistical analysis. SYK and BJP set up the treatment time observation system which is used in the study. MSK participated in the acquisition of cell images. BJK and MAK performed the statistical analysis and helped to interpret data. JCP conceived of the study, and participated in its design and coordination and helped to draft the manuscript. All authors read and approved the final manuscript.

\section{Acknowledgements}

This study was supported by a grant of the Korea Healyhcare technology R\&D project, ministry for health \& welfare, Republic of korea (A120878).

\section{Author details}

${ }^{1}$ Cellbiocontrol Laboratory, Department of Medical Engineering, Yonsei University College of Medicine, 134 Shinchon-dong, Seodaemun-gu, Seoul 120-752, Republic of Korea. ${ }^{2}$ Brain Korea 21 PLUS Project for Medical Science, Yonsei University College of Medicine, 134 Shinchon-dong, Seodaemun-gu, Seoul 120-752, Republic of Korea. ${ }^{3}$ Department of Electrical and Biological Physics and Plasma Bioscience Research Center, Kwangwoon University 305 Dasanjae, 20 Kwangwoongil, Nowon-gu, Seoul 139-701, Republic of Korea.

\section{Received: 1 December 2014 Accepted: 11 April 2015}

\section{Published online: 10 May 2015}

\section{References}

1. Branemark PI, Hansonn BO, Adell R, Breine U, Lindstrom J, Hallen O, et al, Osseointegrated titanium implants in the treatment of the edentulous jaw. Scand J Plast Reconstr Surg. 1977;11:171-5.

2. Albrektsson T, Branemark PI, Hanson HA, Lindstrom J. Osseointegrated titanium implants. Requirements for ensuring a long-lasting, direct bone anchorage in man. Acta Orthop Scand. 1981:52:155-70.

3. Liu X, Chu PK, Ding C. Surface modification of titanium, titanium alloys, and related materials for biomedical applications. Mater Sci Eng R. 2004:47:49-121.

4. Molenberg A, Schwarz F, Herten M, Berner S, de Wild M, Wieland M. Improved osseointegration of a novel, hydrophilic Ti surface-a review. Mat-wiss u Werkstofftech. 2009;40:31-5.

5. Schliephake $H$, Scharnweber D. Chemical and biological functionalization of titanium for dental implants. J Mater Chem. 2008;18:2404-14.

6. Botticelli D, Berglundh T, Buser D, Lindhe J. The jumping distance revisited: an experimental study in the dog. Clin Oral Implant Res. 2003;14:35-42.

7. Rosales-Leala Jl, Rodríguez-Valverdeb MA. Effect of roughness, wettability and morphology of engineered titanium surfaces on osteoblast-like cell adhesion. Colloids and Surfaces A: Physicochem Eng Aspects. 2010:365:222-9.

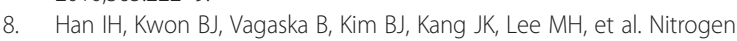
grafting onto polycarprolactone by a simple surface modification with atmospheric pressure glow discharge (Ar-APGD) and promoted neonatal human fibroblast growth. Macromol Res. 2011;19(11):1134-41.

9. Park BJ, Lee DH, Park JC. Sterilization using a microwave-induced argon plasma system at atmospheric pressure. Phys Plasmas. 2003;10:4539-44.

10. Park JC, Park BJ, Han DW, Lee DH, Lee IS, Hyun SO, et al. Fungal sterilization using microwave-induced argon plasma at atmospheric pressure. J Microbiol Biotechnol. 2004;14(1):188-92.

11. Lee KY, Park BJ, Lee DH, Lee IS, Hyun SO, Chung KH, et al. Sterilization of Escherichia coli and MRSA using microwave-induced argon plasma at atmospheric pressure. Surf Coat Tech. 2005;193:35-8.

12. Park BJ, Takatori K, S-Konishi Y, Kim IH, Lee MH, Han DW, et al. Degradation of mycotoxins using microwave-induced argon plasma at atmospheric pressure. Surf Coat Tech. 2007;201:5733-7.

13. Ryu GH, Yang WS, Roh HW, Lee IS, Kim JK, Lee GH, et al. Plasma surface modification of poly ( $D$, L-lactic-co-glycolic acid) $(65 / 35)$ film for tissue engineering. Surf Coat Tech. 2005;193:60-4.

14. Lim HR, Baek HS, Lee MH, Woo Yl, Han DW, Han MH, et al. Surface modification for enhancing behaviors of vascular endothelial cells onto polyurethane films by microwave-induced argon plasma. Surf Coat Tech 2008:202:5768-72.

15. Baek HS, Park YH, Ki CS, Park JC, Rah DK. Enhanced chondrogenic responses of articular chondrocytes onto porous silk fibroin scaffolds treated with microwave-induced argon plasma. Surf Coat Tech. 2008;202:5794-7.

16. Bachmann J, Ellies A, Hartge $\mathrm{KH}$. Development and application of a new sessile drop contact angle method to assess soil water repellency. J Hydrol. 2000;231-232:66-75.

17. Van Oss CJ, Giese Jr RF, Good RJ. Re-evaluation of the surface tension components and parameters of polyacetylene from contact angles of liquids. Langmuir. 1990;6:1711-3.

18. Vandrovcova M, Vacik J, Svorcik V, Slepicka P, Kasalkova N, Vorlicek V, et al. Fullerene C60 and hybrid C60/Ti films as substrates for adhesion and growth of bone cells. Phys Stat Sol (a). 2008;205(9):2252-61.

19. Han IH, Barbora V, Seo HJ, Kang JK, Kwon BJ, Lee MH, et al. Promoted cell and material interaction on atmospheric pressure plasma treated titanium. Appl Surf Sci. 2012;258:4718-23.

20. Anand V, Gowravaram MR. On the purity of atmospheric glow-discharge plasma. IEEE Trans Plasma Sci. 2009;37:1811-6.

21. Takahashi T, Ruan JZ, Kubota S, Shiraishi F. Electron thermalization in argon-nitrogen gas mixture excited by $252 \mathrm{Cf}$ fission fragments. Phys Rev A 1982:25:2820-3.

22. Sun WT, Li G, Li HP, Bao CY, Wang HB, Zeng S, et al. Characteristics of atmospheric-pressure, radio-frequency glow discharges operated with argon added ethanol. J Appl Phys. 2007;101:123302.

23. Huang C, Yu QS, Hsieh F-H, Duan YX. Bacterial deactivation using a low temperature argon atmospheric plasma brush with oxygen addition. Plasma Process Polym. 2007;4:77-87.

24. Shen $H$, Xixue $H$, Yang F, Bei J, Wang S. Combining oxygen plasma treatment with anchorage of cationized gelatin for enhancing cell affinity of poly (lactide-co-glycolide). J Biomaterials. 2007;28(29):4219-30.

25. Davies JE. Understanding peri-implant endosseous healing. J Dent Educ 2003:67(8):932-49.

26. Han IH, Barbora V, Park BJ, Lee MH, Lee SJ, Park JC. Selective fibronectin adsorption against albumin and enhanced stem cell attachment on helium atmospheric pressure glow discharge treated titanium. J Appl Phys. 2011;109:124701-6.

\section{Submit your next manuscript to BioMed Central and take full advantage of:}

- Convenient online submission

- Thorough peer review

- No space constraints or color figure charges

- Immediate publication on acceptance

- Inclusion in PubMed, CAS, Scopus and Google Scholar

- Research which is freely available for redistribution

Submit your manuscript at www.biomedcentral.com/submit

C) Biomed Central 